\title{
Temporal activation of $\beta$-glucanase synthesis in Bacillus subtilis is mediated by the GTP pool
}

\author{
Jörg StülKe, Renate HanschKe and Michael HeckeR* \\ Fachrichtung Biologie, Institut für Mikrobiologie und Molekularbiologie, Ernst-Moritz-Arndt-Universität Greifswald, \\ D-17487 Greifswald, Jahnstraße 15, Germany
}

(Received 16 December 1992; revised 1 March 1993; accepted 25 March 1993)

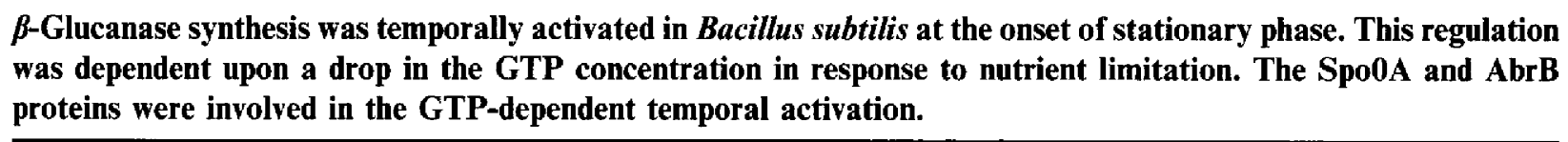

\section{Introduction}

In Bacillus subtilis nutrient limitations trigger the production of numerous extracellular and intracellular enzymes, possibly in order to scavenge alternative nutrient sources. Many of the genes encoding these enzymes are subject to carbon-catabolite repression (for a review see Fisher \& Sonenshein, 1991) and are temporally activated when the cells enter the stationary phase after exhaustion of readily metabolizable nutrients (reviewed by Priest, 1977).

We are interested in the signal chain that leads from a nutrient limitation to the temporal activation of the extracellular enzyme $\beta$-glucanase (endo- $\beta$-1,3-1,4-glucanase, EC 3.2.1.73), the product of the bglS gene. The bglS gene has been cloned (Cantwell \& McConnell, 1983) and sequenced (Murphy et al., 1984). Here we show that the temporal activation of $\beta$-glucanase synthesis is a result of a sharp decrease in the intracellular GTP concentration after a nutrient limitation.

\section{Methods}

Bacterial strains. All B. subtilis strains used in this study are listed in Table 1. The genetic markers of the strains were verified by uridine incorporation experiments for the relA allele and by a test of sporulation for the $\operatorname{spo0A}$ allele.

Media and growth conditions. Cells of $B$. subtilis were grown at $37^{\circ} \mathrm{C}$ in basal limitation medium (BLM) containing nutrients according to the type of limitation required. BLM consists of $50 \mathrm{mM}$-Tris, $15 \mathrm{~mm}$ $\left(\mathrm{NH}_{4}\right)_{2} \mathrm{SO}_{4}, 8 \mathrm{~mm}-\mathrm{MgSO}_{4}, 27 \mathrm{~mm}-\mathrm{KCl}$ and $7 \mathrm{~mm}$-sodium citrate

*Author for correspondence. Tel. 0383477271 ext. 522 ; fax 0383 463345 .
$(\mathrm{pH} 7 \cdot 5)$. The following substances were added from separate stock solutions: $\mathrm{CaCl}_{2}$ to $2 \mathrm{mM}, \mathrm{FeSO}_{4}$ to $1 \mu \mathrm{M}, \mathrm{MnSO}_{4}$ to $10 \mu \mathrm{M}$ and potassium glutamate to $4.5 \mathrm{~mm}$. Amino acid starvation medium (ASM) contained $0.1 \%$ glucose, $0.4 \mathrm{mM} \mathrm{KH}_{2} \mathrm{PO}_{4}$ and $12.8 \mu \mathrm{g} \mathrm{ml}^{-1}$ of each of the required amino acids according to the auxotrophies of the strains. Glucose limitation medium (GLM) was supplemented with $0.05 \%$ glucose, $0.4 \mathrm{~mm}-\mathrm{KH}_{2} \mathrm{PO}_{4}$ and $160 \mu \mathrm{g} \mathrm{ml}^{-1}$ of each of the required amino acids. All media were balanced to support growth to an $\mathrm{OD}_{550}$ of $1 \cdot 2$. The actual starvations were regularly verified by the re-addition of the exhausted nutrient and re-initiation of growth.

For the experiments, $10 \mathrm{ml}$ of medium (BLM containing $0.1 \%$ glucose, $0.6 \mathrm{mM}-\mathrm{KH}_{2} \mathrm{PO}_{4}$, and $160 \mu \mathrm{g} \mathrm{ml}^{-1}$ of each of the required amino acids) was inoculated with one glycerol stock culture. A dilution series of this culture was incubated overnight, and an exponentially growing culture from this series was used as inoculum for the experiments. Experiments were performed in $50 \mathrm{ml}$ batches in $500 \mathrm{ml}$ flasks under vigorous agitation (200 r.p.m.).

Determination of enzyme activity. $\beta$-Glucanase activity was assayed by determination of reducing sugar liberated from lichenan by the dinitrosalicylic acid method (Borriss et al., 1980). One enzyme unit was defined as $1 \mathrm{~mol}$ glucose equivalent produced $\left(\mathrm{OD}_{550} \text { unit }\right)^{-1} \mathrm{ml}^{-1}$ and $\mathrm{s}^{-1}$ (=1 kat). Each enzyme assay was repeated twice. Experiments were performed in duplicate or triplicate. The deviation of results of different experiments was up to $5 \%$. Representative results are shown in the figures.

Determination of nucleotide pools. Cultures were labelled with ${ }^{32} \mathrm{PO}_{4}^{3-}$ $\left(100 \mu \mathrm{Ci} \mathrm{m}^{-1} ; 200 \mathrm{mCi} \mathrm{mmol}^{-1}, 7.4 \mathrm{GBq} \mathrm{mmol}^{-1}\right)$. Nucleotides were

Table 1. B. subtilis strains used in this study

\begin{tabular}{|c|c|c|}
\hline Strain & $\begin{array}{l}\text { Genotype or } \\
\text { phenotype }\end{array}$ & Reference \\
\hline IS56 & $\operatorname{trpC2}$ lys-3 relA & Smith et al. (1980) \\
\hline IS58 & $\operatorname{trpC} 2$ lys-3 & Smith et al. (1980) \\
\hline JH642 & trpC2 phe & Hoch \& Mathews (1973) \\
\hline JH646 & trpC2 phe spoOA & Hoch \& Mathews (1973) \\
\hline ZB449 & trpC2 phe abrB703 & Zuber \& Losick (1987) \\
\hline
\end{tabular}



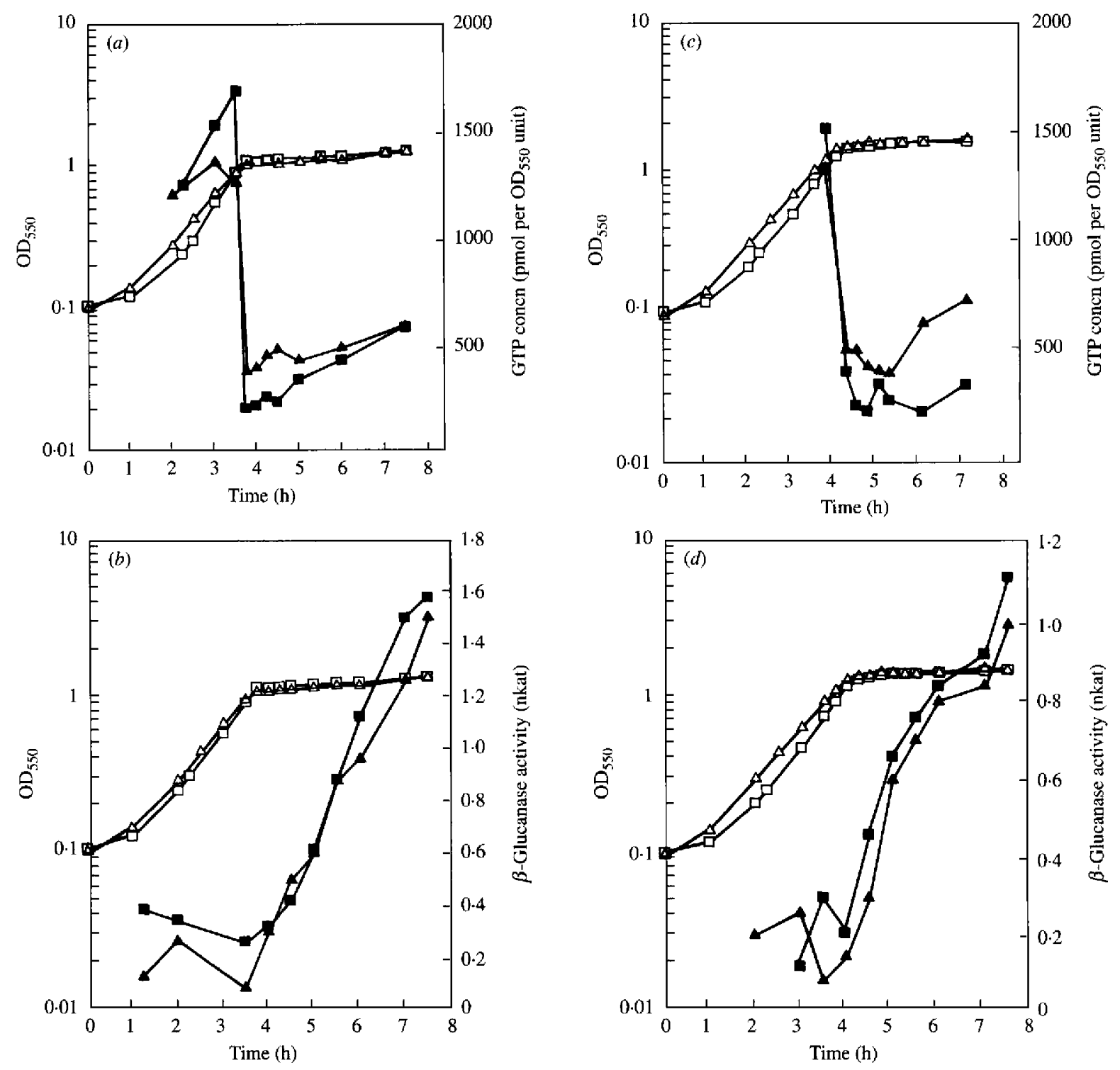

Fig. 1. Growth, intracellular concentration of GTP and $\beta$-glucanase synthesis in B. subtilis IS58 (relA $\left.A^{+}, \square, \boldsymbol{\square}\right)$ and IS56 (relA, $\left.\triangle, \mathbf{\Delta}\right)$ after glucose $(a, b)$ and amino acid limitations $(c, d)$. Cells were grown in GLM or ASM, respectively, and samples were taken as described in the text. $\square, \triangle, \mathrm{OD}_{550} ; \boldsymbol{\square}, \boldsymbol{\Lambda}, \mathrm{GTP}$ concentration $(a, c)$ or $\beta$-glucanase activity $(b, d)$.

extracted using formic acid, analysed by thin-layer chromatography and quantified as described previously (Hecker et al., 1983).

\section{Results and Discussion}

Correlation of growth phase, nucleotide pools and $\beta$ glucanase synthesis

Many authors have presented evidence suggesting that the processes which occur at the onset of the stationary phase are paralleled by an accumulation of the highly phosphorylated guanine nucleotides (p)ppGpp and a sharp decrease of the intracellular GTP concentration (Lopez et al., 1981; Riedel et al., 1987). There are some indications that this decrease is a prerequisite for many of the processes after the cessation of growth (Freese et al., 1979; Nicholson \& Chambliss, 1987). In B. subtilis, the synthesis of (p)ppGpp causes a drastic drop in the GTP concentration (Lopez et al., 1979).

To investigate the involvement of the stringent response in the expression of the $b g l S$ gene, the synthesis of $\beta$-glucanase in the wild-type strain IS58 and in the relA mutant IS56 was compared. Cells were grown in ASM and GLM respectively, and enzyme activities were assayed. In both strains the $\beta$-glucanase activity increased only when the cells stopped growth after either glucose limitation or amino acid starvation (Fig. $1 b, d$ ). These results indicate that the presence of the relA allele does not cause a difference in the expression of $\beta$-glucanase. 

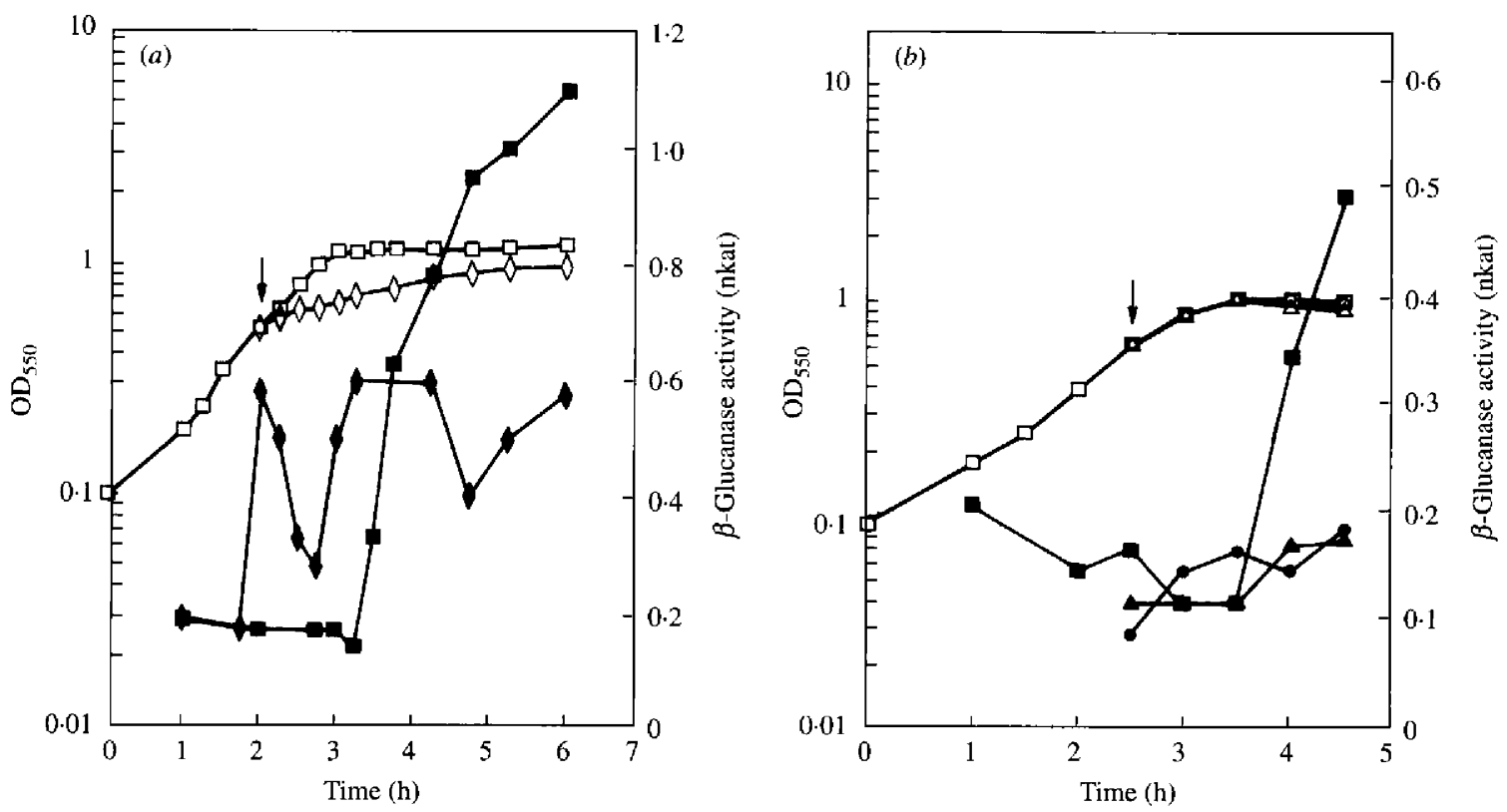

Fig. 2. $\beta$-Glucanase synthesis in strain IS58 (relA ${ }^{+}$) grown in ASM $(\square, \boldsymbol{\square})$. Mid-exponential cultures were divided and decoyinine (a) $(\diamond, \bullet)$, or either guanine $(\triangle, \mathbf{\Delta})$ or guanosine $(O, \bullet)(b)$ was added to parts of the culture (indicated by arrows). $\square, \diamond, \triangle, O, O D_{550}$; $\boldsymbol{\square} \bullet, \mathbf{\Delta}, \boldsymbol{O}, \beta$-glucanase activity.

To determine if there was concomitance of temporal activation and a decrease in the GTP concentration, the nucleotide pools of the stringent and the relaxed strains were analysed. IS58 $\left(\mathrm{Rel}^{+}\right)$and IS56 $(\mathrm{relA})$ were grown in either ASM or GLM. Nutrient limitations resulted in a sharp decrease of intracellular GTP concentration. This applied to both strains, but the drop was slightly more pronounced in the wild-type strain (Fig. 1a,c). Simultaneously, both ATP and phosphoribosyl phosphate concentrations dropped in both strains (data not shown).

\section{Manipulation of purine nucleotide concentration}

In order to verify the significance of the GTP pool for temporal activation, the GTP concentration was manipulated by adding to exponential-phase cultures either decoyinine, an inhibitor of GMP synthetase (Mitani et al., 1977), or purine nucleotides. The responses of $\beta$ glucanase synthesis to these manipulations were measured.

Decoyinine (final concentration $1 \mathrm{mg} \mathrm{m}^{-1}$ ) was added to cultures of IS58 grown in the mid-exponential phase of growth $\left(\mathrm{OD}_{550}=0.5\right)$ in a non-repressing medium (ASM). This resulted in an immediate cessation of growth and in the production of $\beta$-glucanase (Fig. $2 a$ ). This experiment could not prove whether growth inhibition or the drop of the GTP concentration was responsible for temporal activation of $\beta$-glucanase. Therefore either guanine or guanosine was added to mid- exponential cultures of $B$. subtilis IS58 $\left(\mathrm{OD}_{550}=0 \cdot 6\right)$ to $1 \mathrm{mM}$, to prevent a drop of the GTP concentration at the end of growth. In both cases, the addition resulted in a complete loss of temporal activation (Fig. 2b). To obtain further evidence for the involvement of guanine nucleotides the effect of adding adenosine to the culture was investigated. Adenosine addition did not influence the kinetics of $\beta$-glucanase synthesis (data not shown).

\section{Involvement of the spo $0 A$ and abr $B$ gene products}

It is well known that the Spo0A protein is involved in signalling nutrient starvation (Grossman, 1991). As a first step in the elucidation of the regulatory pathway from the signal (drop of GTP concentration) to the expression of the $\beta$-glucanase gene, the involvement of the $\operatorname{spo0A}$ gene in this pathway was addressed.

Strain JH646 $(s p o 0 A)$ produced significantly less $\beta$ glucanase than its isogenic parent JH642 in both ASM and GLM. Furthermore, the synthesis of the enzyme after the onset of stationary phase was delayed in the spo0 $A$ strain by $2.5 \mathrm{~h}$ compared to JH642 (Fig. $3 a$ ).

To obtain further evidence for the involvement of the spo0A gene product in GTP-dependent regulation of $\beta$ glucanase, enzyme synthesis by JH646 after the addition of decoyinine was measured. No stimulation of enzyme synthesis was observed (Fig. $3 b$ ).

The Spo0A protein is a repressor of the $a b r B$ gene (Strauch et al., 1990), whose product in turn represses 

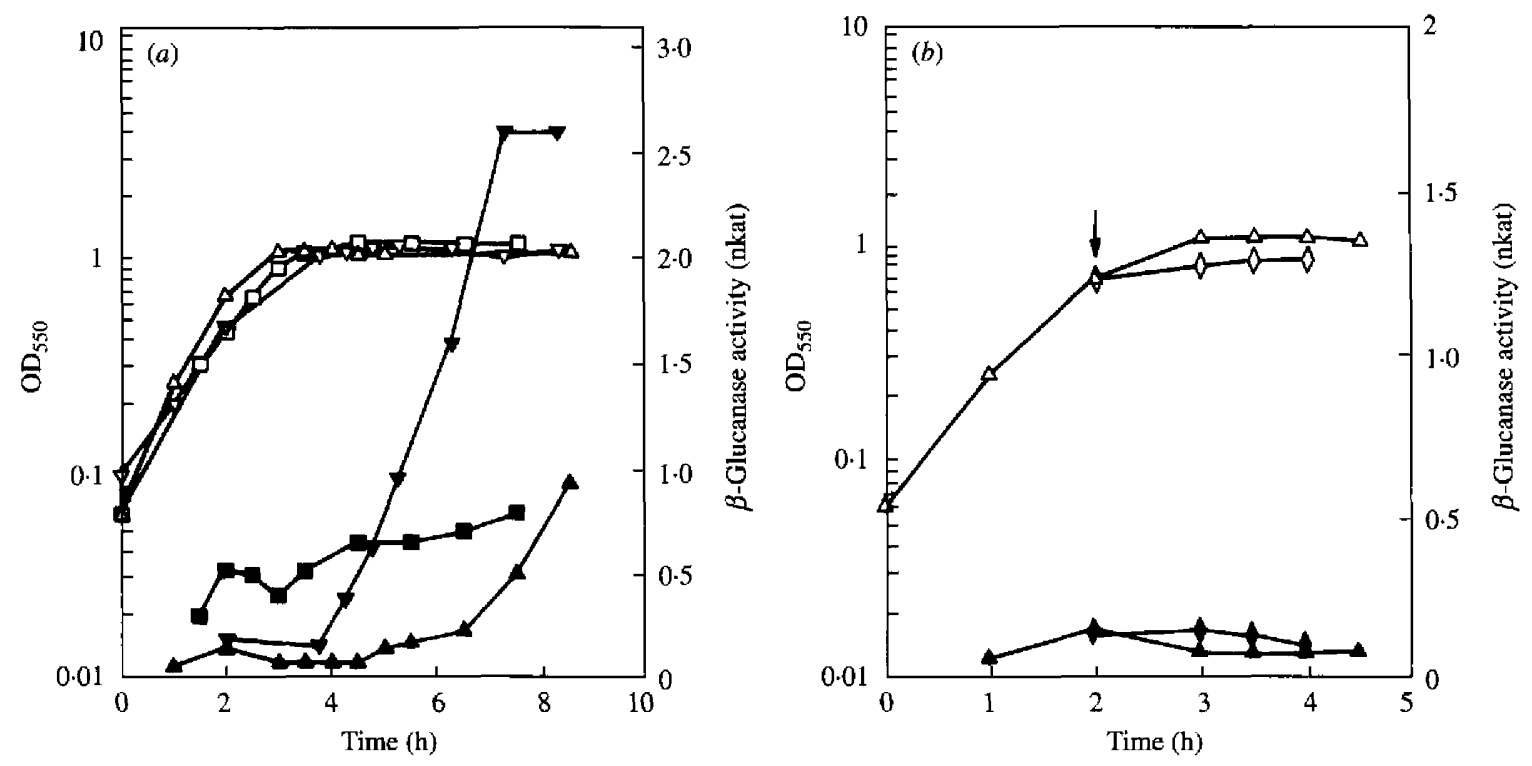

Fig. 3. (a) $\beta$-Glucanase synthesis during growth in strains JH642 (spo0 $\left.A^{+} a b r B^{+}\right)(\nabla, \nabla), J H 646(\operatorname{spo0} A, \triangle, \Delta)$ and ZB449 (abr $B, \square$, $\square$ ). Bacteria were cultivated in ASM. (b) Decoyinine was added to late-exponential cultures of JH646( $\diamond, \bullet)$ as indicated by the arrow. $\nabla, \triangle, \square, \diamond, \mathrm{OD}_{550} ; \boldsymbol{\nabla}, \boldsymbol{\Delta}, \boldsymbol{\square}, \bullet, \beta$-glucanase activity.

many genes during exponential growth (Robertson et al, 1989). The $a b r B$ mutant strain ZB449 showed a fivefold greater activity of $\beta$-glucanase during exponential growth than did the isogenic wild-type JH642 (Fig. $3 a$ ).

\section{Concluding remarks}

We have shown that the expression of $B$. subtilis $\beta$ glucanase is regulated by GTP-concentration-dependent temporal activation. A role for GTP has also been implicated in the regulation of $\alpha$-amylase synthesis (Nicholson \& Chambliss, 1987).

Whereas an inhibition of guanine nucleotide synthesis led to the induction of $\beta$-glucanase synthesis, synthesis of the enzyme was abolished by addition of a guanine nucleotide. These studies allowed the possible effect of the cessation of growth to be distinguished from the effect of a drop of GTP concentration.

The data presented here clearly demonstrate that the decrease in the intracellular GTP concentration at the end of exponential growth is the necessary prerequisite for temporal activation of $\beta$-glucanase synthesis. The spoOA and $a b r B$ genes are probably involved in the signal transduction pathway leading from the decreased intracellular GTP concentration to temporal activation of $\beta$-glucanase synthesis.

We thank W. Hillen for helpful criticism and D. Gärtner for critical reading of the manuscript. A. Tschirner and A. Arelt are acknowledged for their excellent technical assistance. We are grateful to the Upjohn Company, Kalamazoo, for providing us with decoyinine. This work was supported by the Deutsche Forschungsgemeinschaft and the Fonds der Chemischen Industrie.

\section{References}

Borriss, R., Zemek, J., Augustin, J., Pazova, J. \& Koniak, L. (1980). $\beta-1,3-1,4-G$-Gucanase in spore-forming microorganisms. IJ. Production of $\beta$-glucan hydrolases by various Bacillus species. Zentralblatt für Bacteriologie, II. Abteilung 135, 435-442.

CANTwell, B. A. \& McConnell, D. J. (1983). Molecular cloning and expression of a Bacillus subtilis $\beta$-glucanase gene in Escherichia coli. Gene 23, 211-219.

Fisher, S. H. \& Sonenshein, A. L. (1991). Control of carbon and nitrogen metabolism in Bacillus subtilis. Annual Review of Microbiology 45, 107-135.

Freese, E., Heinze, J. \& Galliers, E. M. (1979). Partial purine deprivation causes sporulation of Bacillus subtilis in the presence of excess ammonium, glucose and phosphate. Journal of General Microbiology 115, 193-205.

Grossman, A. D. (1991). Integration of developmental signals and the initiation of sporulation in B. subtilis. Cell 65, 5-8.

HECKER, M., SCHROETER, A. \& MACH, F. (1983). Replication of pBR322 DNA in stringent and relaxed strains of Escherichia coli. Molecular and General Genetics 190, 355-357.

Hoch, J. A. \& Mathews, J. (1973). Chromosomal location of pleiotropic sporulation mutations in Bacillus subtilis. Genetics 73, 215-228.

Lopez, J. M., Marks, C. L. \& Freese, E. (1979). The decrease of guanine nucleotides initiates sporulation of Bacillus subtilis. Biochimica et Biophysica Acta 587, 238-252.

Lopez, J. M., Dromerick, A. \& Freese, E. (1981). Response of guanosine 5 -triphosphate concentration to nutritional changes and its significance for Bacillus subtilis sporulation. Journal of Bacteriology 146, 605-613.

Mitani, T., Heinze, J. E. \& Freese, E. (1977). Induction of sporulation of Bacillus subtilis by decoyinine or hadacidine. Biochemical and Biophysical Research Communications 77, 1118-1125.

Murphy, N. D., MoConNell, D. J. \& Cantwell, B. A. (1984). The DNA sequence of the gene and genetic control sites for the excreted Bacillus subtilis enzyme $\beta$-glucanase. Nucleic Acids Research 12 $5355-5367$. 
Nicholson, W. L. \& Chambliss, G. H. (1987). Effect of decoyinine on the regulation of $\alpha$-amylase synthesis in Bacillus subtilis. Journal of Bacteriology 169, 5867-5869.

PRIEST, F. G. (1977). Extracellular enzyme synthesis in the genus Bacillus. Bacteriological Reviews 41, 711-753.

Riedel, K., Schroeter, A., Liebs, P., Graba, J. P., Hecker, M. \& SCHRAPEL, D. (1987). Formation of extracellular neutral proteinase and the stringent response in Bacillus subtilis. Folia Microbiologica 32, 96-100.

Robertson, J. B., Gocht, M., Marahiel, M. A. \& Zuber, P. (1989). $A b r B$, a regulator of gene expression in Bacillus, interacts with the transcription initiation regions of a sporulation gene and an antibiotic biosynthesis gene. Proceedings of the National Academy of Sciences of the United States of America 86, 8457-8461.

Smith, I., Paress, P., Cabane, K. \& Dubnau, E. (1980). Genetics and physiology of the rel system of Bacillus subtilis. Molecular and General Genetics 178, 271-279.

Strauch, M., Webb, V., Spiegelman, G. \& Hoch, J. A. (1990). The Spo0A protein of Bacillus subtilis is a repressor of the $a b r B$ gene. Proceedings of the National Academy of Sciences of the United States of America 87, 1801-1805.

ZUBER, P. \& Losick, R. (1987). Role of $A b r B$ in SpoOA- and $S p o 0 B$ dependent utilization of a sporulation promoter in Bacillus subtilis. Journal of Bacteriology 169, 2223-2230. 